\title{
Rancang Bangun Website Marketplace dalam Bidang Rental Mobil
}

\author{
Eki Apriliani Dwiningtias, Departemen Ilmu Komputer, Universitas Pelita Harapan Kampus \\ Surabaya, Andreas, Departemen Ilmu Komputer, Universitas Pelita Harapan Kampus Surabaya, dan \\ Hartarto Junaedi, Departemen Sistem Informasi, Institut Sains dan Teknologi Terpadu Surabaya
}

\begin{abstract}
Abstrak-Perkembangan teknologi di dunia mengalami kemajuan yang sangat pesat, khususnya dalam dunia bisnis. Hampir semua bisnis ditawarkan di dunia internet. Tanpa disadari perkembangan teknologi dapat membentuk sebuah wadah untuk menampung penjual dan pembeli yang biasa disebut marketplace. Dengan harapan bisa memberikan kemudahan untuk pembeli dalam mencari produk atau jasa yang dibutuhkan. Sistem ini akan membuat pemilik jasa rental mobil dengan mudah mendapatkan pelanggan yang serius untuk menyewa. Website marketplace rental mobil akan mengurangi transaksi manual antara penyedia jasa dan penyewa. Hal ini berguna bisa mengurangi terjadinya masalah dalam transaksi seperti penipuan atas pembayaran. Transaksi akan berjalan lebih efektif dan efisien. Website ini juga dapat membantu para rental mobil dalam melakukan pencatatan transaksi maupun jumlah uang yang didapat dari hasil penyewaan. Berdasarkan hasil uji coba yang telah dilakukan, dapat disimpulkan bahwa website mempermudah pelanggan dalam mencari mobil yang sesuai dengan kebutuhannya karena terdapat fitur filtering yang bisa mencari mobil sesuai dengan kriteria yang dibutuhkan. Rental mobil juga dapat mendapatkan pelanggan dengan target pasar yang cukup luas karena pelanggan dari berbagai kota. Transaksi menjadi lebih mudah dipantau karena disediakan notifikasi berupa email. Seluruh transaksi tercatat dengan detail dan disediakan laporan dari transaksi.
\end{abstract}

Kata Kunci-Marketplace, Rental Mobil, Sistem, Website.

\section{PENDAHULUAN}

P erkembangan dan pertumbuhan kehidupan di dunia ini telah mengalami perubahan yang sangat luar biasa khususnya pada bidang teknologi. Perkembangan di Indonesia mengakibatkan meningkatnya kebutuhan kendaraan sebagai alat transportasi yang mempermudah manusia dalam melakukan aktivitasnya. Mobil menjadi salah satu alat transportasi yang sangat diminati oleh manusia di era ini. Hal tersebut dikarenakan banyaknya jumlah anggota keluarga di dalam satu keluarga. Tuntutan

\section{Oktober 2020}

Eki Apriliani Dwiningtias, Departemen Ilmu Komputer, Universitas Pelita Harapan Kampus Surabaya, Surabaya, Jawa Timur, Indonesia (email: ed70006@student.uph.edu)

Andreas, Departemen Ilmu Komputer, Universitas Pelita Harapan Kampus Surabaya, Surabaya, Jawa Timur, Indonesia (e-mail: andreas.jodhinata@uph.edu)

Hartarto Junaedi, Departemen Sistem Informasi, Institut Sains dan Teknologi Terpadu Surabaya, Surabaya, Jawa Timur, Indonesia (e-mail: hartarto.j@gmail.com) kegiatan yang mengharuskan setiap orang sampai di lokasi tujuan dengan aman dan nyaman juga menjadi alasan mengapa mobil begitu penting.

Dalam kehidupan perorangan mobil juga sudah menjadi kebutuhan utama setiap orang. Setiap keluarga membutuhkan mobil pribadi untuk melakukan sebuah perjalanan jauh atau pada cuaca yang kurang bersahabat. Terkadang orang tidak berani membawa mobil pribadi ke luar kota karena tidak mengenal area tersebut. Memiliki resiko yang cukup tinggi membuat orang lebih memilih tidak membawa mobil sendiri untuk melakukan sebuah perjalanan. Dengan menggunakan mobil pribadi juga membuat pengeluaran menjadi lebih banyak karena selain biaya operasional juga harus membayar pajak dan perawatan. Mengenai pengeluaran hal ini juga dirasakan dalam dunia bisnis, setiap perusahaan juga harus melakukan hal tersebut jika memiliki mobil operasional tetap.

Rental mobil merupakan bentuk usaha penyewaan mobil yang sangat membantu dan memiliki permintaan yang tinggi. Untuk menyewa mobil pelanggan harus datang kepada pihak rental yang mungkin tidak hanya satu tempat. Hal ini terkadang menyulitkan pelanggan karena harus menentukan pilihan rental mana yang bisa dipercaya dan memiliki harga sewa yang paling ekonomis.

Membangun jasa rental mobil online juga bukanlah hal yang mudah. Banyaknya pesaing membuat jasa rental mobil online sulit memasarkan mobil-mobilnya. Jasa rental mobil online harus melakukan strategi pemasaran yang berbeda dari yang lain agar mampu bersaing dengan para pesaingnya. Jika dilihat dari sisi pelanggan, mencari harga yang ekonomis dan berkualitas namun bisa diakses dengan mudah adalah tujuan utama para pelanggan. Fitur-fitur yang memudahkan dalam hal transaksi ini sangat dicari oleh para pelanggan, mengingat bahwa pada era ini setiap orang lebih menyukai hal-hal yang efisien. Banyaknya rintangan atau hambatan inilah yang membuat jasa rental mobil online sulit untuk berkembang.

Dalam rancang bangun sistem marketplace terdapat beberapa masalah yang dihadapi seperti:

1) Bagaimana masyarakat bisa mendapatkan informasi yang lengkap mengenai mobil sewa dengan mudah dan hemat waktu?

2) Hal apa saja yang bisa dilakukan pihak rental mobil agar dapat bersaing dalam menawarkan produknya dalam sistem yang berbasis web? 
3) Bagaimana cara meyakinkan pelanggan mengenai mobil yang dipilih?

4) Bagaimana cara menerapkan sistem marketplace rental mobil berbasis website?

5) Bagaimana menerapkan proses sewa mobil yang baik agar proses sewa mudah tanpa adanya masalah?

6) Apa yang harus diperhatikan agar pihak rental tertarik daftar ke marketplace yang akan dibuat?

7) Bagaimana cara mengatur jika mobil yang sudah disewa agar tidak bisa disewa orang lain?

\section{TEORI PENUNJANG}

\section{A. E-Commerce}

E-commerce merupakan bagian dari e-bussiness yang berhubungan dengan pembelian dan pemasaran produk dan jasa melalui internet atau media elektronik lainnya. Hal ini juga mencakup aktivitas yang mendukung transaksi pasar yaitu periklanan, pemasaran, dukungan pelanggan, keamanan, pengiriman, dan pembayaran [1]. Terdapat beberapa tipe dari e-commerce, Ada banyak klasifikasi mengenai transaksi e-commerce berdasarkan dari sifat pesertanya. Tiga kategori utama dari e-commerce yaitu Business to Consumer (B2C), Business to Business (B2B), dan Consumer to Consumer (C2C).

Pada B2C e-commerce melibatkan produk dan layanan retail untuk pembeli individu atau konsumen. Berrybenka yang menjual barang fashion kepada konsumen adalah contoh dari B2C. Berbeda lagi dengan B2B e-commerce, pada B2B e-commerce melibatkan penjualan barang dan jasa antar bisnis. Bizzy yang merupakan platform supply chain terintegrasi untuk logistik dan distribusi di Indonesia adalah contoh dari B2B. Selanjutnya pada C2C e-commerce yang melibatkan konsumen menjual langsung ke konsumen. Ebay yang merupakan situs lelang yang memungkinkan orang menjual barang mereka ke konsumen lain dengan penawar tertinggi, atau dengan harga tetap adalah contoh dari C2C. Namun seiring berjalannya waktu C2C dianggap menjadi model bisnis dimana konsumen dari marketplace yang menawarkan produk atau jasa kepada konsumen lainnya. Kasus ini seperti pada sistem yang akan dibangun dimana rental mobil menawarkan jasa kepada pelanggan tapi tidak bertemu langsung pada saat melakukan transaksi, hanya melalui website yang akan dibuat.

E-commerce memiliki banyak kelebihan. Namun tentunya e-commerce juga memiliki kekurangan didalamnya. Berikut adalah kelebihan dan kekurangan ecommerce dari sisi konsumen maupun dari sisi penyedia layanan [2]:

1) Kelebihan e-commerce dari sisi konsumen:

a. Belanja sangat mudah karena operasi sepanjang waktu yaitu layanan 24 x 7 .

b. Belanja tanpa perlu antri, dengan catatan internet telah tersedia dan software yang disediakan telah dibuat dengan tepat.

c. Belanja dengan mudah tanpa harus keluar rumah, dengan e-commerce konsumen bisa belanja dimanapun dan kapanpun dengan mudah. d. Kebutuhan konsumen dapat dipenuhi, jika keinginan konsumen sesuai dengan yang ditawarkan.

e. Penawaran dengan jangkauan global dan harga yang ditawarkan lebih murah.

2) Kelebihan e-commerce dari sisi penyedia layanan:

a. Layanan untuk konsumen dapat dilakukan dengan lebih baik.

b. Komunikasi dengan konsumen dapat lebih cepat karena mudahnya menghubungi konsumen tanpa menggunakan telepon hanya cukup menggunakan live chat komunikasi menjadi lebih cepat.

c. Potensi mendapatkan konsumen sangat tinggi karena e-commerce memiliki jangkauan lebih luas.

3) Kekurangan e-commerce dari sisi konsumen:

a. Pencurian data, hal ini sering terjadi biasanya dalam hal pembayaran. Mudahnya melakukan pembayaran dengan memasukkan nomor kartu kredit biasanya kartu kredit mudah dibobol. Hal ini bisa diatasi jika website memiliki keamanan security yang cukup baik

b. Pencurian identitas, biasanya nomer KTP, nomer telepon dan lain sebagainya yang dapat disalahgunakan.

c. Penyalahgunaan, identitas yang dicuri biasanya digunakan untuk berbelanja lalu pengiriman dilakukan dirumah pemilik identitas yang mengakibatkan pemiliki alamat harus membayar belanja.

d. Perusahaan palsu, perusahaan tidak pernah ada namun perusahaan melakukan penipuan. Penipuan ini dilakukan dengan cara menawarkan suatu produk atau jasa lalu konsumen membeli dan membayar, namun barang tidak akan dikirim sampai kapanpun. Bahkan biasanya perusahaan tidak bisa dihubungi

e. Status hukum yang tidak pasti, jadi sulit untuk menuntut jika terjadi kesalahan.

4) Kekurangan e-commerce dari sisi penyedia layanan:

a. Biaya pengiriman tinggi jika konsumen memiliki alamat lokasi yang cukup jauh, namun hal ini juga dapat diatasi dengan memberikan biaya pengiriman untuk ditanggung oleh konsumen.

b. Sulit membuat iklan dengan harapan mendapatkan target yang sesuai.

\section{B. Marketplace}

Marketplace atau ada juga yang menyebutnya emarketplace merupakan bagian dari e-commerce. Marketplace adalah media komunitas bisnis interaktif yang menyediakan ruang pasar pusat dimana banyak perusahaanperusahaan yang terlibat dalam kegiatan B2B e-commerce atau kegiatan e-business lainnya. Marketplace dapat dikatakan sebagai gelombang kedua dalam penyebaran ecommerce serta memperluas kombinasi antara Bisnis dan Konsumen (B2C, C2B dan C2C) ke dalam area Business-toBusiness (B2B) [3].

Marketplace dapat dikategorikan menjadi dua jenis yaitu, marketplace horisontal dan marketplace vertikal. Berikut penjabarannya [3]:

1) Marketplace horisontal dikategorikan berdasarkan fungsi atau produk umum yang ditawarkan oleh perusahaan. 
Pasar yang digunakan untuk industri umum dapat diartikan seperti pasar penjualan baju, smartphone, pc dan lain sebagainya. Hal ini yang dimaksud adalah marketplace horisontal tidak menawarkan spesifik produk atau jasa pada industri tertentu. Produk atau jasa yang ditawarkan tidak hanya satu namun sangat beragam, dari berbagai macam industri dan cenderung tidak terbatas. Marketplace horisontal memiliki kelebihan didalamnya yaitu biaya transaksi yang dikeluarkan relatif lebih rendah dalam proses pembelian, sementara harga yang lebih rendah juga memberikan keuntungan untuk pembeli. Namun, banyaknya keanekaragaman produk atau jasa membuat pelanggan sulit melakukan kolaborasi yang efektif dengan efek pada efisiensi rantai suplai secara keseluruhan.

2) Marketplace vertikal diartikan menjadi pasar yang digunakan sebagai industri yang memenuhi kebutuhan spesifik dalam masing-masing industri. Dalam hal ini produk atau jasa yang ditawarkan sangat spesifik pada industri tertentu seperti, jasa rental mobil, komputer dan lain sebagainya. Marketplace vertikal juga memiliki keuntungan didalamnya yaitu positioningnya untuk mengelola kebutuhan khusus dan kustom pada setiap industrinya sehingga timbul kolaborasi yang lebih efektif dibanding dengan marketplace horisontal.

Untuk menerapkan e-marketplace harus memiliki strategi agar mendapatkan hasil yang optimal. Kemunculan marketplace memiliki keuntungan yang bisa didapatkan didalamnnya marketplace dapat mengurangi biaya transaksi pembelian bagi pembeli dan memperbesar peluang usaha bagi penjual serta dapat mengurangi resiko dalam penjualan. Dengan marketplace produk atau jasa milik penjual dapat dengan mudah dipasarkan tanpa perlu mengeluarkan upaya maupun biaya yang besar karena telah sudah disediakan tempat untuk meletakkan produk atau jasanya. Adanya marketplace membuat penjual semakin bersaing secara ketat dalam memasarkan produk yang dimiliki, para pelaku usaha melakukan penurunan harga produk atau jasa yang ditawarkan untuk menaklukan para pembeli. Pembeli akan menseleksi beberapa marketplace dan akan memilih satu diantaranya, dengan demikian faktor kepercayaan menjadi sangat penting untuk membangun marketplace agar proses transaksi dapat berlanjut [4].

\section{Rental Mobil}

Rental mobil adalah bisnis atau usaha yang menawarkan jasa penyewaan mobil kepada konsumen yang membutuhkan. Penawaran jasa ini dilakukan pada perorangan maupun perusahaan. Pelaku usaha harus memahami satu hal yaitu penyewa atau konsumen tidak bertanggung jawab atas perbaikan mobil. Dalam hal ini yang bertanggung jawab penuh atas mobil rental adalah pemilik. Untuk mengurangi resiko yang terjadi pemilik rental mobil harus memiliki asuransi untuk melindungi mobil yang disewakan. Rental mobil juga memiliki sistem penyewaan yang beragam ada yang menggunakan sistem penyewaan mobil dengan sopir dan tidak menggunakan sopir yang biasa disebut lepas kunci. Hal ini tergantung kebutuhan penyewa kendaraan. Jika menginginkan sistem penyewaan dengan sopir maka pemilik rental wajib memiliki sopir yang dapat memberikan pelayanan terbaik. Sistem lepas kunci yang dimaksud disini adalah menyewa mobil tanpa harus didampingi sopir ataupun sumber daya manusia yang berkaitan dengan rental, sistem lepas kunci murni bahwa pelaku menyerahkan mobil kepada konsumen [5]. Hal ini memiliki resiko yang cukup tinggi namun hal ini dapat diatasi dengan adanya asuransi yang akan melindungi dan kecanggihan teknologi yaitu GPS (Global Positioning System) yang memudahkan pelaku usaha untuk memantau mobil yang digunakan penyewa tanpa sepengetahuan penyewa [6].

\section{Metodologi Penelitian}

\section{A. Analisa Sistem}

Pada sistem marketplace rental mobil akan menyediakan hak akses yang berbeda-beda bagi admin marketplace, rental mobil, dan pelanggan. Setiap user yang telah mendaftar ke sistem dapat melakukan login dengan username dan password masing-masing. Khusus rental mobil dan pelanggan wajib melakukan validasi email untuk melanjutkan aktivitas login. Pada saat login setiap user akan diarahkan kepada dashboard yang berbeda-beda sesuai kebutuhan.

Bagian admin memiliki 2 jabatan yang diberikan hak akses berbeda dengan tujuan agar kerja admin lebih efektif dan efisien. Admin dengan jabatan maintenance akan diberikan akses backend dengan memiliki wewenang untuk mengatur dan mengawasi seluruh proses yang dilakukan rental mobil dan pelanggan termasuk melunasi tagihan pembayaran kepada rental mobil apabila penyewaan benarbenar selesai. Pembayaran kepada pihak rental mobil akan dipotong $10 \%$ dari total pembayaran. Sedangkan Admin dengan jabatan finance hanya akan mendapatkan track record pembayaran dari pelanggan dan pembayaran ke rental mobil, selain itu juga bisa melihat laporan pendapatan.

Bagian rental mobil bisa melakukan create, read, dan update akun. Setiap rental mobil bisa melakukan create, read, update dan delete mobil dan sopir. Delete mobil dan sopir hanya dilakukan penggantian status dari active menjadi deleted dan tidak benar-benar dihapus. Informasi mengenai penyewaan akan didapatkan oleh pihak rental mobil pada halaman data pemesanan dan email rental mobil yang terdaftar. Apabila pemesanan jenis with driver maka rental harus memberikan nama sopir yang akan melayani pelanggan pada pemesanan tersebut. Namun, dalam hal ini sopir diberikan oleh pihak rental, tidak otomatis oleh sistem melainkan dipilih sesuai sopir rental yang tersedia menurut pihak rental dan bisa diganti sewaktu-waktu apabila sopir berhalangan. Sopir yang terpilih akan diberikan email, selain sopir pelanggan juga akan mendapatkan email mengenai nama sopir yang akan melayani pemesanannya. Secara garis besar, seluruh aktivitas yang dilakukan rental mobil akan akan ditangani oleh admin rental mobil. Rental mobil akan diberikan keuntungan dengan akan menerima laporan yang akan dibuatkan oleh admin marketplace. 


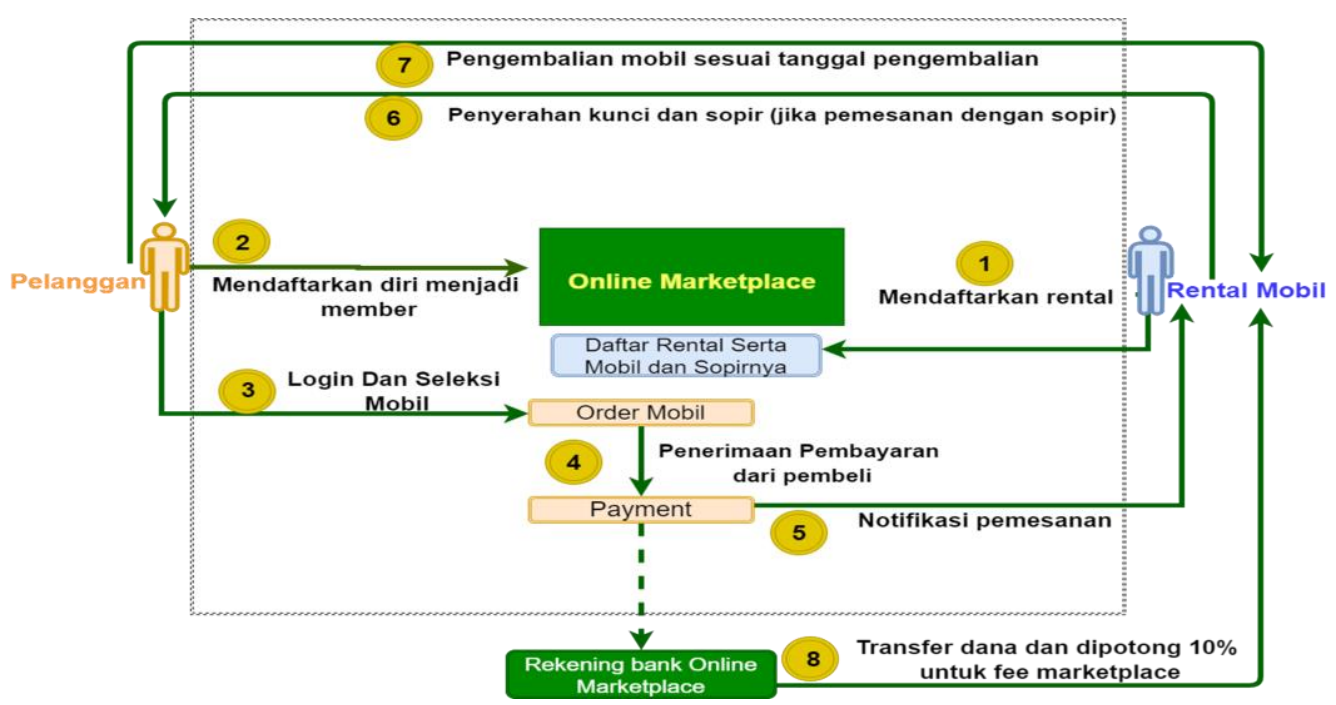

Gambar. 1. Diagram Proses Website Marketplace Rental Mobil

Bagian pelanggan bisa melakukan create, read dan update pada akun. Aktivitas login akan memberikan katalog mobil sesuai dengan kebutuhan pelanggan. Pelanggan juga bisa mobil yang mungkin bisa dikatakan baik karena pernah dipesan oleh pelanggan lain dengan membaca review yang telah disediakan. Pada saat diberikan katalog mobil pelanggan juga bisa memfilter sesuai dengan kebutuhannya. Filter yang disediakan yaitu harga tertinggi, harga termurah, jenis bahan bakar mobil maupun tahun mobil (2016-2020). Jika sesuai dengan yang diinginkan maka pelanggan bisa melakukan pemesanan dengan mudah. Pemesanan dihitung per hari yaitu 24 jam penuh.

Pemesanan yang telah dilakukan oleh pelanggan harap dilunasi dalam waktu 1 jam agar pemesanan bisa diproses oleh admin marketplace. Pemesanan yang tidak dibayarkan dalam waktu 1 jam maka pemesanan otomatis ke cancel. Bukti pembayaran akan di cek oleh admin marketplace jika pembayaran sesuai dengan yang ditagihkan maka penyewaan berhasil dan akan diberikan email bukti pembayaran diterima. Setelah pelanggan menyelesaikan pemesanannya, maka pelanggan akan diberikan form review untuk mengisi rating dan deskripsi mengenai mobil yang dipesan. Review akan dibaca dan dikelola oleh admin marketplace, review yang telah di baca dan dikelola oleh admin marketplace akan diteruskan kepada pihak rental mobil agar rental mobil bisa mengerti bagaimana kondisi mobil yang disewa pelanggan. Pelanggan juga akan mendapatkan riwayat transaksi mengenai pemesanannya selama ini.

\section{B. Alat Bantu Analisis Sistem}

\section{1) Diagram Proses}

Diagram Proses memberikan gambaran mengenai proses berjalannya website yang lebih mudah dibaca dan bersifat umum. Diagram proses pada website yang akan dirancang dapat dilihat pada Gambar 1. Pada diagram ini dijelaskan secara urut mengenai tata cara penggunaan website untuk user. Setiap proses diberikan angka untuk mempermudah pembacaan.
2) Diagram Konteks

Diagram konteks memberikan gambaran umum mengenai proses utama yang ada dalam sebuah sistem yang akan dikembangkan. Maka sangat diperlukan pembuatan diagram konteks dalam merancang sebuah sistem. Penerapan diagram konteks ini diterapkan dalam pembuatan perancangan sistem marketplace rental mobil. Pada diagram konteks perancangan sistem marketplace rental mobil yang akan dibangun melibatkan tiga entitas dengan hak akses dan fungsinya masing-masing. Tiga entitas tersebut adalah admin marketplace, rental mobil dan pelanggan.

3) Data Flow Diagram Nol dan Satu (DFD)

DFD Level nol merupakan penjelasan lebih detail dari diagram konteks. Dalam diagram ini akan dijelaskan proses utama dalam sistem yang akan digambarkan dengan data flow dan data store. Untuk DFD Level Satu adalah penjelasan lebih detail mengenai proses yang sudah terbentuk dalam DFD Level nol.

4) Entity Relationship Diagram (ERD)

Entity Relationship Diagram (ERD) menjelaskan mengenai rancangan database yang digunakan dalam sistem marketplace rental mobil. ERD tergambar dalam bentuk tabel yang saling berhubungan. Setiap tabel memiliki primary key dan nama-nama kolom yang dimiliki tabel tersebut.

\section{IMPLEMENTASI PROGRAM}

\section{A. Home}

Halaman home merupakan halaman awal yang akan tampil apabila user mengakses website. Terdapat beberapa fitur yang ada pada halaman home seperti form untuk mencari katalog, sekilas isi about us, dan layanan yang ditawarkan. Mengenai fitur dapat dilihat pada Gambar 2.

\section{B. Register dan Login}

Register merupakan halaman yang digunakan pelanggan untuk mendaftarkan diri menjadi member dan untuk melanjutkan aktivitas login. Untuk register sebagai rental mobil memiliki nama Join as Partner. Join as partner 
memiliki fungsi yang sama seperti register untuk melanjutkan aktivitas login. Untuk halaman login merupakan halaman yang berfungsi untuk mendapatkan dashboard masing-masing user sesuai kebutuhan. Algoritma mengenai proses register dapat dilihat pada algoritma (1). Pada Algoritma (1) merupakan contoh dari register pelanggan yang juga hampir sama dengan register rental mobil. Keduanya memiliki kewajiban untuk menerima email verifikasi agar bisa melakukan aktivitas login.
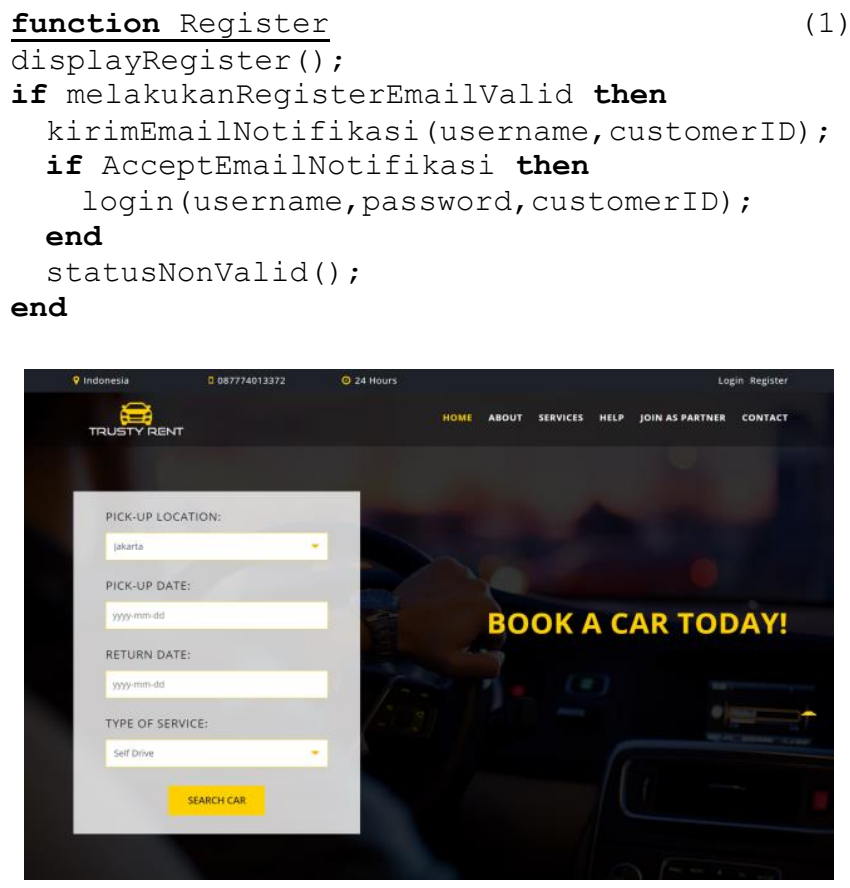

Gambar. 2. Halaman Home

\section{Katalog dan Filtering}

Katalog mobil adalah halaman yang dapat diakses dengan mengisi form search car pada halaman home. Setelah mengisi sesuai keinginan yang ingin dicari maka pilih tombol search car maka akan diarahkan kepada katalog mobil yang sesuai kebutuhan. Namun untuk ke katalog mobil user wajib melakukan login terlebih dahulu. Pada katalog terdapat fasilitas pagination dan filtering. Pagination pada tampilan katalog bertujuan agar tidak terlalu banyak mobil yang ditampilkan, agar tampilan tidak di scroll terus kebawah, sedangkan filtering berfungsi untuk mempermudah pencarian mobil sesuai kebutuhan. Pada katalog terdapat rating mobil yang berfungsi untuk membantu pelanggan memilih mobil mana yang bisa dipilih untuk disewa. Tidak hanya rating review pelanggan lain juga dapat dilihat dengan memilih tombol "Review (jumlah review)".

\section{Pemesanan}

Pemesanan adalah halaman yang akan didapatkan oleh pelanggan apabila menekan tombol book pada salah satu katalog. Pemesanan dilakukan oleh pelanggan untuk menyewa mobil. jika pemesanan berhasil dilakukan maka pelanggan akan mendapatkan notifikasi berupa email dan dianjurkan mengunggah bukti pembayaran dalam batas waktu 1 jam. Algoritma mengenai proses pemesanan dapat dilihat pada algoritma (2).

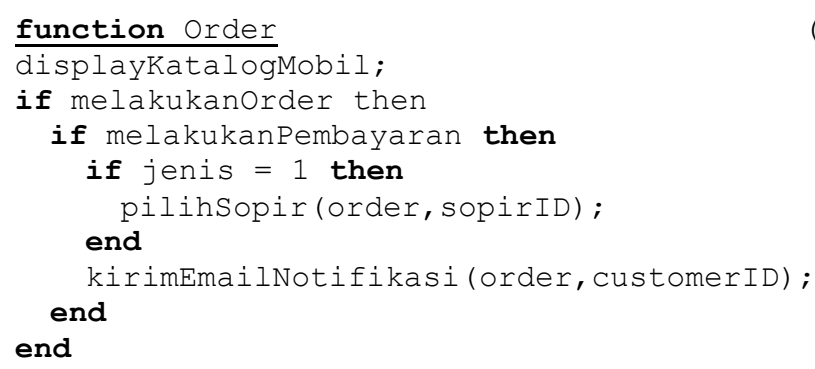

\section{E. Form Pembayaran}

Form pembayaran adalah halaman untuk pelanggan mengupload bukti pembayaran yang telah digunakan. Untuk pengisian form yang telah disediakan berguna untuk mempermudah admin (maintenance) dalam pengecekan bukti pembayaran pelanggan. Form pembayaran tidak bisa didapatkan jika pembayaran lebih dari 1 jam. Apabila belum melakukan pembayaran lebih dari 1 jam maka pemesanan otomatis dibatalkan oleh sistem. Bukti pembayaran yang dikirim akan dicek oleh admin agar pemesanan bisa diproses lebih lanjut.

\section{F. Form Review}

Form review diberikan untuk pelanggan agar pelanggan dapat memberikan ulasan mengenai pelayanan, mobil, dan kepuasan pelanggan terhadap fasilitas yang telah diberikan. Untuk review ada 2 jenis tipe yaitu services atau complain jadi pelanggan akan memilih tipe jenis review yang mana yang akan dituliskan. Hasil dari ulasan pelanggan bisa dilihat pada dashboard rental mobil maupun dashboard admin maintenance. Jika mobil memiliki rating yang tidak baik maka admin akan menghubungi rental mobil untuk menindaklanjuti keluhan dari pelanggan.

\section{G. Pengaturan Akun Pelanggan}

Pengaturan akun pelanggan untuk mengatur informasi mengenai pelanggan tersebut. Ada beberapa hal yang tidak bisa diatur yaitu username dan email karena keduanya sudah terdaftar dan tervalidasi tidak dapat dirubah. Namun, jika seperti nama lengkap, alamat, nomer telepon bisa diubah. Selain hal diatas pelanggan juga dapat melakukan perubahan password hal ini digunakan untuk membantu pelanggan jika merasa password yang dimiliki sudah tidak aman dan merasa terlalu mudah untuk dibobol oleh orang lain.

\section{H. Dashboard Admin}

Halaman utama yang dapat diakses oleh admin (maintenance) setelah melakukan proses login adalah dashboard admin (maintenance). Dashboard admin (maintenance) akan menampilkan beberapa informasi penting seperti total profit pada tahun sekarang, total profit pada bulan sekarang, total pelanggan dan total rental mobil. Pada dashboard admin (maintenance) juga terdapat grafik mengenai perkembangan profit dari bulan ke bulan. Grafik ini bisa menunjukkan apakah marketplace mengalami penaikan atau penurunan. 

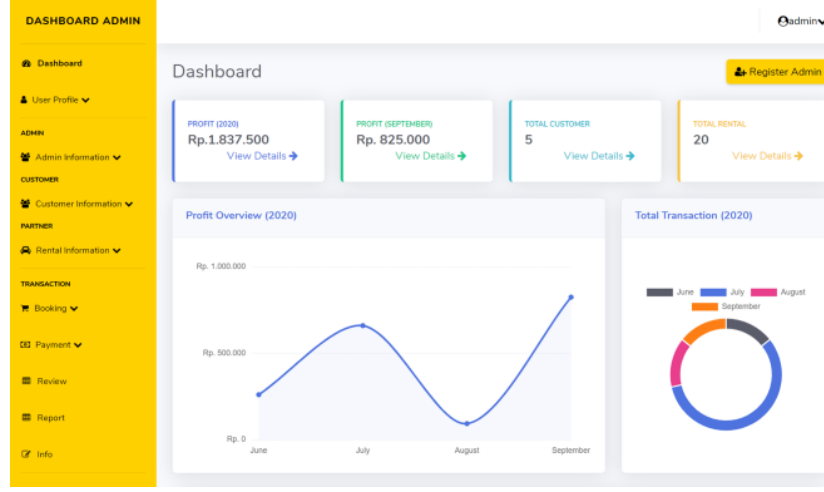

Gambar. 3. Dashboard Admin

Pada Gambar 3 Dashboard admin juga terdapat pie chart mengenai total transaksi setiap bulannya. Pada dashboard admin (maintenance) juga terdapat tabel dengan 2 baris yang menunjukkan pemesanan terbaru. Hal ini berguna untuk mempermudah admin (maintenance) dalam melihat pemesanan yang terbaru tanpa harus pindah ke halaman menu booking.

\section{Pengaturan Akun Admin}

Pengaturan akun admin untuk mengatur informasi mengenai admin tersebut. Ada beberapa hal yang tidak bisa diatur yaitu username, email, dan jabatan karena keduanya sudah terdaftar dan tervalidasi tidak dapat dirubah. Namun, jika seperti nama lengkap bisa diubah. Selain hal diatas admin juga dapat melakukan perubahan password hal ini digunakan untuk membantu admin jika merasa password yang dimiliki sudah tidak aman dan merasa terlalu mudah untuk dibobol oleh orang lain.

\section{J. Register Admin Finance}

Register admin finance adalah halaman yang hanya ada pada dashboard admin maintenance. Halaman ini digunakan oleh admin maintenance untuk melakukan pendaftaran admin finance.

\section{K. List User}

Halaman list user seperti pelanggan, admin maupun rental mobil terdapat tabel dan sebuah fasilitas untuk search maupun sorting. Halaman ini akan menampilkan seluruh data user yang pernah melakukan registrasi ke sistem. Untuk list pelanggan juga terdapat sebuah aksi pada tabel yang dapat digunakan oleh admin (maintenance) yaitu fasilitas untuk melihat detail pelanggan dan inactive akun pelanggan apabila melakukan kesalahan atau hal-hal yang melanggar aturan. Pelanggan yang telah di inactive tidak akan bisa login dan melakukan pemesanan lagi, namun inactive akun tidak akan berpengaruh pada transaksi-transaksi yang sudah pernah dilakukan. Sedangkan pada list rental mobil juga terdapat sebuah aksi yang dapat digunakan oleh admin (maintenance) yaitu fasilitas untuk melihat detail rental mobil, data mobil berdasarkan rental, dan inactive akun rental mobil apabila melakukan kesalahan atau hal-hal yang melanggar aturan. Rental mobil yang telah di inactive tidak akan bisa login dan menyewakan mobil-mobilnya lagi, namun inactive akun tidak akan berpengaruh pada transaksitransaksi yang sudah ada.

\section{List Pemesanan}

Halaman list pemesanan terdapat tabel dan sebuah fasilitas untuk search maupun sorting. Halaman ini akan menampilkan seluruh informasi pemesanan yang dilakukan oleh pelanggan. Pada tabel juga terdapat sebuah aksi yang dapat digunakan oleh admin (maintenance) yaitu fasilitas untuk melihat detail pemesanan dan konfirmasi pembayaran namun akan dialihkan ke halaman data pembayaran pelanggan. Aksi konfirmasi pembayaran hanya tombol bantuan untuk melihat apakah ada pembayaran masuk apabila admin (maintenance) sedang berada pada halaman data pemesanan. Hal ini dilakukan untuk mempercepat pengecekan konfirmasi bukti pembayaran.

\section{List Pembayaran Pelanggan}

Halaman list pembayaran pelanggan terdapat tabel dan sebuah fasilitas untuk search maupun sorting. Halaman ini akan menampilkan seluruh data pembayaran yang dilakukan oleh pelanggan. Pada tabel juga terdapat sebuah aksi yang dapat digunakan oleh admin (maintenance) yaitu fasilitas konfirmasi pembayaran pelanggan. Konfirmasi pembayaran pelanggan dilakukan setelah dilakukan cek pembayaran pelanggan. Setelah admin (maintenance) mengkonfirmasi pembayaran maka sistem akan memberikan notifikasi pada pelanggan dan rental mobil. Jenis pemesanan with driver akan diberikan nama sopir oleh pihak rental setelah pembayaran berhasil. Terdapat aksi lain yang akan tampil apabila transaksi pelanggan telah memiliki status transaction finished yaitu payment. Aksi payment dapat dilakukan oleh admin untuk menuju ke pembayaran untuk rental.

\section{N. Pembayaran ke Rental}

Pada halaman pembayaran ke rental ini terdapat sebuah fasilitas untuk search maupun sorting. Halaman ini akan menampilkan seluruh data pembayaran yang akan menunjukkan pemesanan mana yang harus dilakukan pelunasan ke rental mobil. Pada tabel ini terdapat sebuah aksi yang dapat digunakan admin (maintenance) untuk mengupload bukti pembayaran ke rental mobil. Aksi tombol payment akan tampil apabila transaksi pemesanan sudah dinyatakan transaction finished oleh rental mobil. Rental mobil juga akan menerima notifikasi berupa email mengenai pembayaran yang diterima dari admin untuk dikonfirmasi.

\section{O. Dashboard Rental Mobil}

Halaman utama yang dapat diakses oleh rental mobil setelah melakukan proses login adalah dashboard rental mobil. Dashboard rental mobil akan menampilkan beberapa informasi penting seperti total income pada tahun sekarang, total mobil, total sopir dan total booking atau pemesanan yang dinyatakan selesai (transaction finished). Pada dashboard rental mobil juga terdapat grafik mengenai perkembangan income dari bulan ke bulan. Grafik ini bisa menunjukkan apakah rental mobil mengalami penaikan atau penurunan.

Pada Gambar 4 Dashboard Rental Mobil juga terdapat tabel dengan 2 baris yang menunjukkan pemesanan terbaru. Hal ini berguna untuk mempermudah rental mobil dalam 
melihat pemesanan yang terbaru tanpa harus pindah ke halaman menu booking. Pada dashboard rental mobil juga disediakan fasilitas untuk melakukan edit profile, change password dan buka atau tutup rental mobil. Fasilitas edit profile dan change password bisa dilakukan dengan memilih tanda panah kebawah disebelah nama akun rental mobil. Mengenai buka dan tutup rental mobil dapat dilakukan jika rental mobil sudah tidak memiliki transaksi yang sedang berjalan.

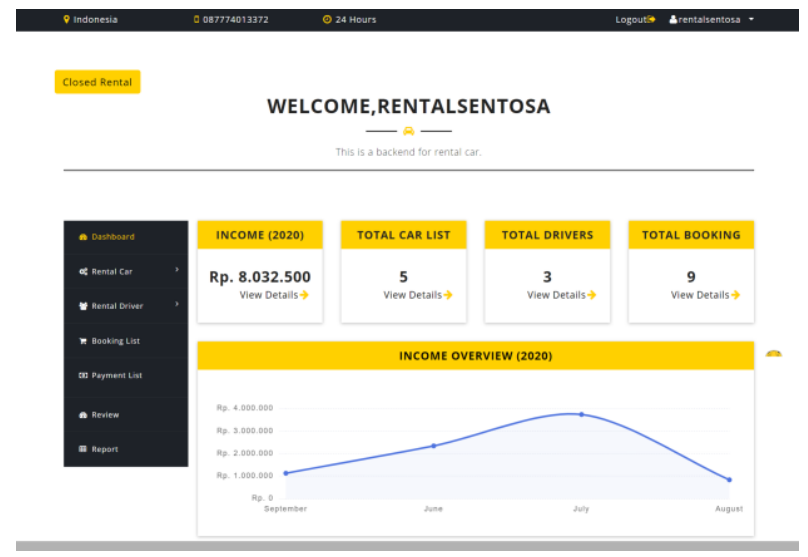

Gambar. 4. Dashboard Rental Mobil

\section{P. Tambah Mobil dan Sopir}

Tambah mobil adalah proses memasukkan data mobil pada sistem terdapat pada menu insert car pada sistem. Pada halaman ini rental mobil dapat mendaftarkan semua mobilnya yang bertujuan untuk disewa oleh pelanggan. Rental mobil harus mengisi semua form sesuai informasi mobil yang ada. Rental mobil juga harus memberikan gambar yang akan ditampilkan pada katalog pelanggan. Sedangkan tambah mobil adalah proses memasukkan data sopir pada sistem terdapat pada menu insert driver yang terdapat pada sistem. Pada halaman ini rental mobil dapat mendaftarkan semua sopirnya yang akan melayani pemesanan with driver. Rental mobil harus mengisi semua form sesuai informasi sopir yang dimiliki. Email sopir yang didaftarkan merupakan email sopir yang aktif dan dapat menerima notifikasi mengenai transaksi yang akan dilayani.

\section{Q. Pilih Sopir}

Halaman yang akan tampil jika pemesanan jenis with driver. Halaman ini akan memilih nama sopir yang akan melayani pemesanan jenis with driver. Setelah memilih sopir maka sopir akan diberikan notifikasi agar membantu sopir untuk mengerti harus melayani pelanggan hari apa saja. Sopir yang terpilih bisa diganti oleh rental mobil sewaktu-waktu jika sopir berhalangan. Selain sopir pelanggan juga akan diberikan notifikasi mengenai nama sopir yang akan melayani.

\section{R. Laporan Pendapatan}

Halaman data laporan pendapatan untuk rental mobil juga akan menampilkan beberapa laporan mengenai 5 mobil teratas pada tahun sekarang berdasarkan waktu terlama dipesan oleh pelanggan, 5 mobil teratas pada tahun sekarang berdasarkan pemesanan terbanyak oleh pelanggan, dan detail pendapatan pada tahun sekarang. Untuk 5 mobil teratas keduanya disajikan dalam bentuk horizontal bar chart. Mengenai detail pendapatan rental mobil dapat melihat lebih detail dari detail pendapatan dan sudah disediakan tombol untuk ke halaman detail income.

\section{S. Pengaturan Akun Rental Mobil}

Pengaturan akun rental mobil untuk mengatur informasi mengenai rental mobil tersebut. Ada beberapa hal yang tidak bisa diatur yaitu username dan email karena keduanya sudah terdaftar dan tervalidasi tidak dapat dirubah. Namun, jika seperti nama rental, nama pemilik, telepon dan lain sebagainya bisa diubah. Selain hal diatas rental mobil juga dapat melakukan perubahan password hal ini digunakan untuk membantu rental mobil jika merasa password yang dimiliki sudah tidak aman dan merasa terlalu mudah untuk dibobol oleh orang lain.

\section{KESIMPULAN}

Kesimpulan yang didapat setelah melalui proses pengembangan website marketplace rental mobil adalah sebagai berikut:

1) Website ini dapat mempermudah pelanggan dalam mencari mobil yang sesuai dengan kebutuhannya karena disediakan fitur filtering yang bisa mencari mobil sesuai dengan kriteria yang dibutuhkan.

2) Website ini dapat mengatasi masalah keamanan transaksi, pelanggan tidak akan melakukan pembayaran diluar sistem untuk menghindari adanya penipuan. Pelanggan hanya akan mengetahui nama rental pada saat penyerahan mobil yang disewa.

3) Dengan website marketplace rental mobil dapat menjangkau target pasar yang lebih luas, karena pelanggan yang didapatkan bisa dari seluruh kota yang ada Indonesia.

4) Website ini akan membantu user dalam memantau transaksi, dari sisi pelanggan akan diberikan notifikasi berupa email jika telah melakukan pemesanan maupun pembayaran dan dari sisi rental mobil juga akan diberikan notifikasi mengenai transaksi dari pelanggan (jika pelanggan telah melunasi pembayaran) maupun pembayaran dari marketplace.

5) Website ini mempermudah rental mobil dalam memantau grafik pemasukan setiap bulannya, karena disediakan fitur pemberian laporan dengan detail mengenai pemasukan rental mobil.

\section{DAFTAR PUSTAKA}

[1] Laudon, K. C. (2014). Management Information Systems: Managing the Digital Firm, 13th Edition. United States of America: Pearson Education.

[2] Kütz, M. (2016). Introduction to E-commerce: Combining Business and Information Technology 1st Edition. Martin Kütz \& bookboon.com.

[3] e-Marketplaces: Crafting A Winning Strategy. Brunn, P., Jesen, M. \& Skovgaard, J., European Management Journal, 2002, 286-298.

[4] Abdurrozzaq Hasibuan, J. J. (2020). E-Business: Implementasi, Strategi dan Inovasinya. Yayasan Kita Menulis.

[5] Rini, M. (2006). 120 Solusi Mengelola Keuangan Pribadi. Indonesia: Elex Media Komputindo. 
[6] PLUS, T. A. (2013). Top 50 Bisnis Paling Untung Bos. Penebar PLUS+.

Eki Apriliani Dwiningtias menyelesaikan pendidikan di SD Masangan Kulon, Sidoarjo tahun 2010, telah menyelesaikan pendidikan di SMP Negeri 22, Surabaya 2013, telah menyelesaikan pendidikan di SMA Hang Tuah 2, Sidoarjo tahun 2016 dan menempuh kuliah di Universitas Pelita Harapan Kampus Surabaya pada tahun 2017 dengan Program Studi S1 Sistem Informasi, Fakultas Ilmu Komputer. 